\title{
Formation des mots
}

(voir dérivation)

\section{OpenEdition}

\section{Journals}

Édition électronique

URL : http://journals.openedition.org/encyclopedieberbere/1956

DOI : 10.4000/encyclopedieberbere.1956

ISSN : 2262-7197

Éditeur

Peeters Publishers

Édition imprimée

Date de publication : 1 février 1998

Pagination : 2897

ISBN : 2-85744-994-1

ISSN : $1015-7344$

\section{Référence électronique}

«Formation des mots », Encyclopédie berbère [En ligne], 19| 1998, document F38, mis en ligne le 01

juin 2011, consulté le 25 septembre 2020. URL : http://journals.openedition.org/encyclopedieberbere/ 1956 ; DOI : https://doi.org/10.4000/encyclopedieberbere.1956

Ce document a été généré automatiquement le 25 septembre 2020.

(c) Tous droits réservés 


\section{Formation des mots}

(voir dérivation) 